\title{
Are They Really Stem Cells? Scrutinizing the Identity of Cells and the Quality of Reporting in the Use of Adipose Tissue-Derived Stem Cells
}

\author{
Ernesto Balolong, ${ }^{1}$ Soojung Lee, ${ }^{1,2}$ Judee Grace Nemeno, ${ }^{1}$ and Jeong Ik Lee ${ }^{1,3}$ \\ ${ }^{1}$ Regenerative Medicine Laboratory, Center for Stem Cell Research, Department of Biomedical Science and Technology, Institute of \\ Biomedical Science and Technology, Konkuk University, 120 Neungdong-ro, Gwangjin-gu, Seoul 143-701, Republic of Korea \\ ${ }^{2}$ Regeniks Co., Ltd., Seoul, Republic of Korea \\ ${ }^{3}$ Department of Veterinary Medicine, College of Veterinary Medicine, Konkuk University, Seoul 143-701, Republic of Korea
}

Correspondence should be addressed to Judee Grace Nemeno; judee_nemeno@yahoo.com and Jeong Ik Lee; jeongik@konkuk.ac.kr

Received 31 July 2015; Revised 5 September 2015; Accepted 9 September 2015

Academic Editor: Giuseppe A. Ferraro

Copyright (C) 2016 Ernesto Balolong et al. This is an open access article distributed under the Creative Commons Attribution License, which permits unrestricted use, distribution, and reproduction in any medium, provided the original work is properly cited.

\begin{abstract}
There is an increasing concern that the term adipose tissue-derived stem cell (ASC) is inappropriately used to refer to the adipose stromal vascular fraction (SVF). To evaluate the accuracy and quality of reporting, 116 manuscripts on the application of ASC in humans and animals were examined based on the 2013 published International Federation for Adipose Therapeutics and Science (IFATS)/ International Society for Cellular Therapy (ISCT) joint statement and in reference to current guidelines for clinical trials and preclinical studies. It is disconcerting that 4 among the 47 papers or $8.51 \%$ (CI 2.37-20.38) surveyed after publication of IFATS/ISCT statement reported using ASCs but in fact they used unexpanded cells. 28/47 or 59.57\% (CI 44.27-73.63) explicitly reported that adherent cells were used, $35 / 47$ or $74.47 \%$ (CI 59.65-86.06) identified expression of surface markers, and $25 / 47$ or $53.19 \%$ (CI 14.72-30.65) verified the multilineage potential of the cells. While there are a number of papers examined in this survey that were not able to provide adequate information on the characteristics of ASCs used with some erroneously referring to the SVF as stem cells, there are more room for improvement in the quality of reporting in the application of ASCs in humans and animals.
\end{abstract}

\section{Introduction}

The use of adipose tissue-derived stem cells (ASC) has gained popularity as alternative to bone marrow derived stem cells or to human embryonic stem cells, particularly as the manner by which the source tissue is collected is less invasive compared to the former and does not have serious ethical issues compared to the latter. In view of pronouncements on the beneficial use of stem cells in the popular media [1], acknowledging the real therapeutic potential of stem cells is yet to be made as the scientific community is just starting to unravel their efficacy and safety [2].

There has been a major confusion though in the use of the term adipose tissue-derived stem cells, with some authors referring to the heterogeneous stromal vascular fraction (SVF) after centrifugation as stem cells. To provide guidance on this, the International Federation for Adipose Therapeutics and Science (IFATS) and International Society for Cellular Therapy (ISCT) in 2013 published a joint statement regarding the characteristics and differences of the two portions when derived from the adipose tissue with recommendations on how both should be ascertained [3]. A number of other guidelines and expert opinions also have been published in relation to the use of stem cells in clinical trials and the importance of reporting guidelines for preclinical studies [4-9].

Our objective is to determine the exact identity of the ASCs used in human patients and animal subjects as reported in published papers and the quality of reporting in reference to existing guidelines and expert recommendations. 


\section{Materials and Methods}

The search engine Pubmed (http://www.pubmed.org/) was used to come up with the list of manuscripts and publications related to researches or clinical reports employing ASC in human patients and animal subjects from January 2011 to June 2015. For a report to be included in this survey, it must indicate adipose tissue-derived stem cells in either the title or the abstract. The keyword "adipose tissue-derived mesenchymal stem cells" combined with "clinical trial," "therapy," or "patient" was used to generate the list. We excluded from the list review articles and those reports that utilize ASC for in vitro experimentation only. Relevant articles were initially identified by the title and abstract and subsequently each paper was examined further by verifying whether indeed the use of ASC was reported and applied in either human patients or animal subjects. It is acknowledged that this search method was not exhaustive as there are manuscripts in journals that are not included in Pubmed.

We evaluated the papers in four key characteristics to ascertain the identity of cells used in reference to the IFATS and ISCT recommendations. These include (1) the use of expanded cells as treatment regimen, alone or in combination with other agents, (2) explicitly mentioning plastic adherent cells that were used, (3) phenotyping of surface markers, and (4) conducting multilineage differentiation of the expanded cells. We divided the papers further into two groups to examine the impact of the IFATS and ISCT statement on how authors would report the identities of the cells used. These were the before IFATS/ISCT statement group, comprised of papers published during the period 2011-2013, and the after IFATS/ISCT statement group, comprised of papers published on 2014-2015.

For papers utilizing ASC in human patients, the key areas considered were ethics (reported undergoing ethical review and approval for the study via an institutional review, reported obtaining an informed consent, and reported clinical trial registration), safety (processing the cells in Good Manufacturing Practice or GMP facility, testing for genomic stability, and contaminants prior to use), and cell characteristics (viability, number of cell passages, and number of cells administered). For papers utilizing ASC in animal subjects, the key areas considered were ethics (reporting of oversight and approval of the study via the Animal Care and Use Committee), study design (allocation to groups/randomization, calculation of sample size, and blinding), experimental animals (species, sex, age, and group size), and cell characteristics (viability, number of passages, and number of cells delivered).

\section{Statistical Analysis}

Data are presented as number, proportion, and percentages with binomial 95\% confidence interval. Proportions were analyzed using Fisher Exact Test and post hoc analysis using the statistical software GraphPad Prism. The results are presented as percentages with $95 \%$ confidence intervals and a value of $P<0.01$ was considered to be statistically significant.
TABLE 1: Papers included in this survey that reported on the use of ASC for human and veterinary clinical trials.

\begin{tabular}{lccc}
\hline Classification & $\begin{array}{c}\text { Source of adipose } \\
\text { tissue for ASC }\end{array}$ & $\begin{array}{c}\text { Type of } \\
\text { transplantation }\end{array}$ & References \\
\hline $\begin{array}{l}\text { Human clinical } \\
\text { trial }\end{array}$ & Human & $\begin{array}{c}\text { Autologous } \\
\text { Allogeneic }\end{array}$ & {$[10-39]$} \\
{$[37,40-44]$} \\
\hline $\begin{array}{l}\text { Veterinary } \\
\text { clinical trial }\end{array}$ & Animal & Autologous & {$[45,46]$} \\
\hline
\end{tabular}

\section{Results}

4.1. Overall Description of Selected Articles. The electronic search identified 623 articles. Based on the title, abstract, and description of the paper, a total of 149 papers were shortlisted after all the review articles, duplicates, and papers not relevant to the survey were removed. Only 116 papers were retrieved for evaluation after manuscripts not complying with our criteria were taken out further from the list [10-125]. All in all, 34 papers reported the use of ASC in human patients, 81 papers reported the use of ASC in animal subjects, and 1 paper reported the use of ASC in both human and animals. Based on the year of publication, 69 papers were grouped as before IFATS/ISCT statement group while 47 papers were determined to comprise the after statement group. $88.57 \%(31 / 35)$ of papers reporting application for human use were clinical trials while $11.43 \%$ (4/35) were case reports. $81.71 \%(67 / 82)$ of the papers involving animal use were human preclinical studies, 3.66\% (3/82) were veterinary clinical trials, and $2.44 \%(2 / 82)$ were veterinary preclinical studies. $12.20 \%(10 / 82)$ were classified as basic research. Table 1 summarizes the specific papers in this survey that were classified as human and veterinary clinical trial.

We observed in this survey varying sources of adipose tissue from where the lipoaspirates and cells were derived. Overall, 27.59\% (32/116) had human patients as sources, $26.72 \%$ (31/116) utilized tissues from human donors, $27.59 \%$ (32/116) derived the tissues from animal subjects and $12.07 \%$ (14/116) from animal donors, $0.86 \%$ (1/116) reported utilizing human adipose tissue-derived stem cell from a commercial source, $0.86 \%(1 / 116)$ utilized tissues from human patients and human donors, another $0.86 \%$ (1/116) derived the tissues from human donor and animal subjects, and 2.59\% (3/116) derived the tissues from a human donor and an animal donor, while the remaining $0.86 \%$ (1/116) did not indicate the source of the tissue. We also classified the papers according to the nature of cell transplantation whether it will be autologous, allogeneic, or xenogeneic. Most of the papers on human application reported autologous use at 80\% (28/35), with $14.28 \%(5 / 35)$ being allogeneic; $2.86 \%$ (1/35) were not classified as no source was indicated while the last $2.86 \%$ $(1 / 35)$ were both autologous and allogeneic. For animal studies, most are allogeneic at $42.68 \%(35 / 82)$ or xenogeneic at $40.24 \%(33 / 82) .12 .20 \%(10 / 82)$ are autologous and $4.88 \%$ $(4 / 82)$ are both allogeneic and xenogeneic. Majority of the reports at $85.34 \%(99 / 116)$ indicated benefits results with the use of ASC while 12.93\% (15/116) indicated otherwise. 
TABLE 2: Summary of papers that reported human application of ASC according to the route of delivery of stem cells.

\begin{tabular}{lc}
\hline Route of delivery & References \\
\hline Intra-arterial & {$[37]$} \\
Intra-articular & {$[17,42]$} \\
Intradermal & {$[11,35]$} \\
Intramuscular & {$[10,27]$} \\
Intravenous & {$[13-15,41,43,44]$} \\
Injection at submucosal, & {$[12,16,28,40]$} \\
mucosal, and tract wall & {$[13,14,18,26,33]$} \\
Subcutaneous & {$[21,26,31,38]$} \\
Transplanted with scaffold & \\
material or tissue graft &
\end{tabular}

TABLE 3: Summary of papers that reported human application of ASC according to solution used to resuspend ASCs prior to delivery of cells.

\begin{tabular}{lc}
\hline Carrier used & References \\
\hline Culture medium with human albumin & {$[40]$} \\
Hyaluronic acid & {$[33]$} \\
Lactated Ringer's solution & {$[32]$} \\
Normal saline & {$[11]$} \\
Saline with 1\% human albumin & {$[14]$} \\
\hline
\end{tabular}

Various routes of administration of ASC in humans were observed in this survey as indicated in the papers depending on which site the cells are expected to settle. These include intra-arterial, intra-articular, intradermal, intramuscular, and intravenous injection at the submucosal, mucosal, and subcutaneous layer or transplanted with the scaffold material and tissue graft. Table 2 summarizes the papers included in this survey that reported route of delivery of the ASCs. Table 3 presents the carrier used to resuspend the stem cells before use or administration of the cells in humans as reported by specific papers included in this survey. These include the use of culture medium with human albumin, stabilized hyaluronic acid, lactated Ringer's solution, and normal saline with or without $1 \%$ human albumin. Majority of the papers did not indicate the specific medium used.

\subsection{Impact of IFATS and ISCT Statement. Figure 1 illustrates} the percentage of papers in reporting the primary characteristics of mesenchymal stem cells. There are still a number of papers which failed to conduct appropriate tests to verify the identity of the cells they use. Fisher Exact Test results showed significant difference in proportions $(P<0.05)$ in the before $(n=69)$ and after statement groups $(n=$ 47) when reporting the use of adherent cells. There were no significance differences in the reporting of the surface markers and multilineage differentiation but there are a number of papers that failed to report such characteristics at the after statement group. $28 / 47$ or $59.57 \%$ (CI 44.27-73.63) explicitly reported adherent cells (Figure 1(b)) were used and $35 / 47$ or $74.47 \%$ (CI 59.65-86.06) identified expression of surface markers (Figure 1(c)). Meanwhile, 25/47 or $53.19 \%$
TABle 4: Comparison on reporting of data on cell characteristics between papers grouped prior to and after publication of IFATS/ISCT statement on ASCs.

\begin{tabular}{lccc}
\hline $\begin{array}{l}\text { Cell } \\
\text { characteristic }\end{array}$ & $\begin{array}{c}\text { Description of data } \\
\text { reported }\end{array}$ & $\begin{array}{c}\text { Number of articles } \\
\text { Prestatement } \\
(n=69)\end{array}$ & $\begin{array}{c}\text { Poststatement } \\
(n=47)\end{array}$ \\
\hline Expanded cells & $\begin{array}{c}\text { Use of expanded } \\
\text { cells } \\
\text { Did not use } \\
\text { expanded cells }\end{array}$ & 52 & 42 \\
& $\begin{array}{l}\text { Implied use } \\
\text { Reported use }\end{array}$ & 10 & 4 \\
Adherent cells & $\begin{array}{c}\text { Did not report } \\
\text { Implied use }\end{array}$ & 7 & 1 \\
\hline $\begin{array}{l}\text { Phenotyping } \\
\text { of surface } \\
\text { markers }\end{array}$ & $\begin{array}{c}\text { Phenotyping done } \\
\text { No phenotyping }\end{array}$ & 48 & 28 \\
\hline $\begin{array}{l}\text { Differentiation } \\
\text { potential }\end{array}$ & $\begin{array}{c}\text { Conducted } \\
\text { Did not conduct }\end{array}$ & 34 & 19 \\
\hline
\end{tabular}

(CI 38.08-67.89) verified the differentiation potential of the cells (Figure 1(d)). Of these 25,1 paper reported verifying only the osteogenic potential while 4 papers did the differentiation tests but nevertheless used unexpanded cells for the treatment groups. While there was no significant difference observed when comparing the before and after statement groups as far as the use of expanded cells is concerned (Figure 1(a)) disaggregating the data according to human (before statement, $n=22$, after statement group $n=13$ ) and animal (before statement group $n=47$, after statement group $n=$ 35) application showed significant difference $(P<0.001)$ and post hoc analysis indicates the difference when comparing papers with animal application to papers with human application of ASC (Figure 2). All of the 11 papers in this survey that did not use cultured and expanded cells but indicated they were using ASC instead of SVF were reports of application in humans. There is no significant difference between the human before statement group $(7 / 22$ or $31.82 \%$, CI 13.87-54.87) and human after statement group (4/13 or $30.77 \%$, CI 9.09-61.43). Table 4 summarizes the frequency of papers that reported information on the characteristics of the cells used.

4.3. Quality of Reporting on ASC Use in Humans. Figure 3 shows the percentages with $95 \%$ confidence interval of papers reporting on human application of ASC $(n=35)$ on selected parameters. There are $4 / 35$ or $11.43 \%$ (CI 3.20-26.74) papers that did not indicate obtaining approval from an institutional review board. Of these 4, 3 reports were case studies while 1 paper was a preclinical study and, of the 4 case reports included in this survey, 1 paper reported having obtained an approval. $5 / 35$ or $14.29 \%$ (CI 4.81-30.26) did not report having obtained informed consent from either patient or tissue donors. Of these 5, 2 papers were case reports while 3 papers were clinical studies. Only $10 / 35$ or $28.57 \%$ (CI $14.64-46.30$ ) reported processing the tissues and cells in GMP conditions. Of the $20 / 35$ or $57.14 \%$ (CI 39.35-73.68) conducted tests for 


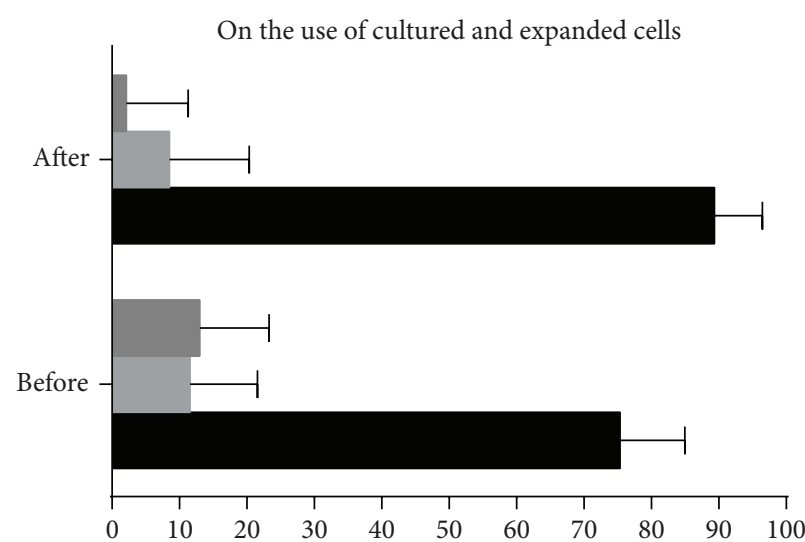

(\%)

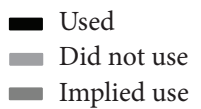

(a)

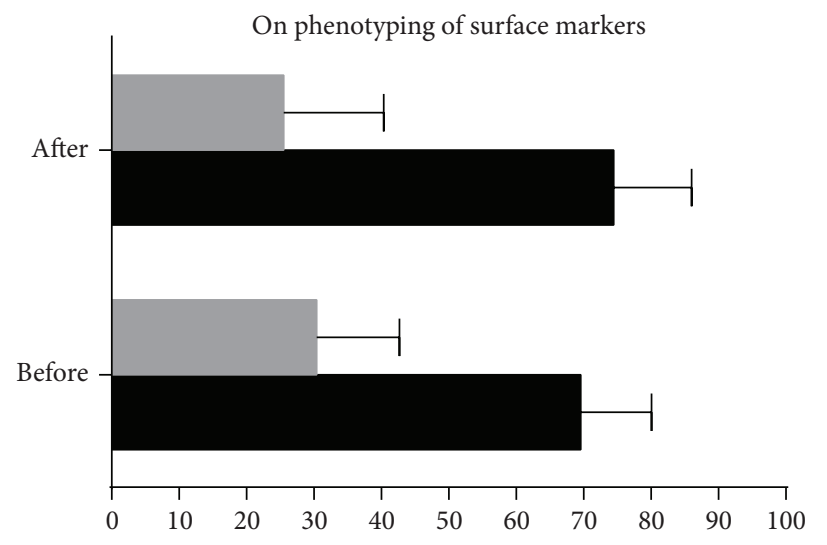

(\%)

Identified

- Did not identify

(c)

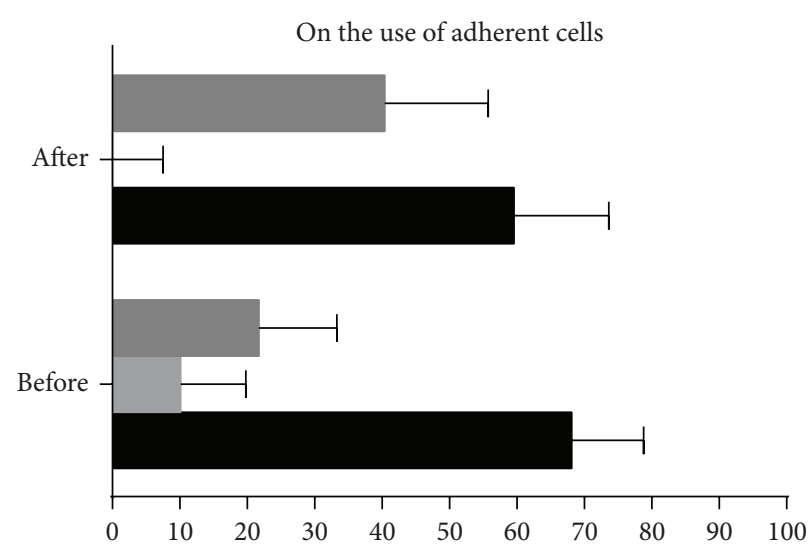

(\%)

Reported

- Did not report

Implied use

(b)

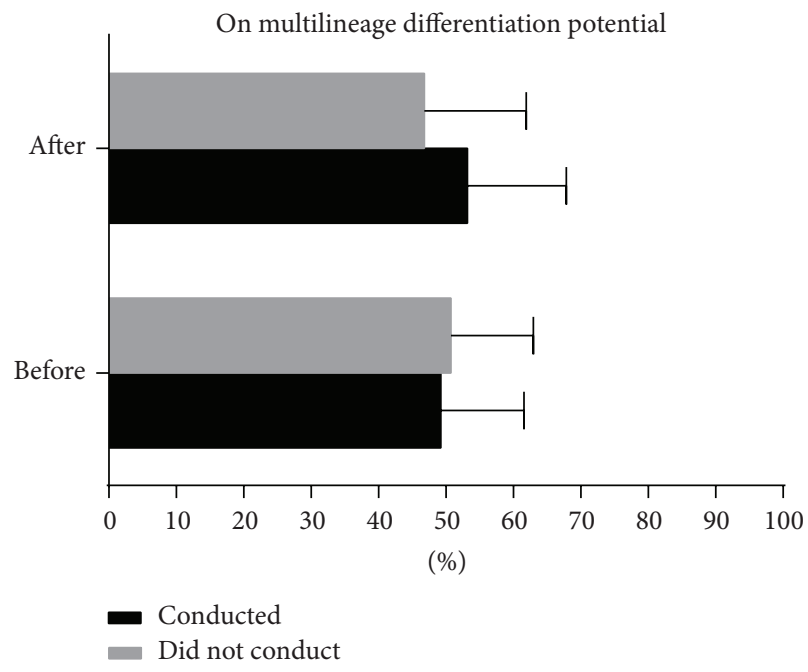

(d)

FIGURE 1: Impact of IFATS and ISCT on reporting of the characteristics of the ASC. Papers reporting on the characteristics of the cells transplanted or delivered to human patients or animal subjects were grouped and assessed before $(n=69)$ and after $(n=47)$ publication of the IFATS and ISCT statement.

possible contamination before using the expanded cells, 1 paper reported testing for 5 different types of contaminants (viral, bacterial, fungal, mycoplasma, and endotoxin), 1 paper reported testing for 4 types, 6 papers reported testing for 2-3 types, and 11 papers reported testing for 1 type of contaminant. Of these 11, 10 papers tested for bacterial contamination, while 1 conducted endotoxin testing. More than half of these papers surveyed (19/35 or $54.28 \%$, CI $36.35-71.89)$ did not report conducting cell viability while only $7 / 35$ (20\%, CI 8.44-36.94) checked the genomic stability of the cells. As to the number of cells delivered during transplantation $24 / 35$ (68.57\%, CI 50.71-83.15) reported actual cell numbers while 8/35 (22.86\%, CI 10.42-40.14) indicated the number of passages at the time the expanded cells were used. Table 5 summarizes the frequency of papers that reported on selected key areas and parameters of ASC use in humans.
4.4. Quality of Reporting on ASC Use in Animals. Figure 4 presents percentages with confidence interval of papers reporting on animal application of ASC on selected parameters. Among the 82 papers reporting on animal application of ASC, there are 35 papers of those that utilized human adipose tissue as source for mesenchymal stem cells. Of these 35, 24 or $68.57 \%$ (CI 50.71-83.15) reported on obtaining informed consent from human donors while a lesser number of $16 / 35$ (45.71\%, CI 28.83-63.35) reported on having obtained approval from an institutional review board for the use of human samples. $7 / 82$ or $8.54 \%$ (CI 3.5-16.80) did not report obtaining an approval from an animal welfare ethics committee. All papers reported the species used but $35 / 82$ or $42.68 \%$ (CI 31.82-54.10) reported the age of their subjects while $69 / 82$ or $84.15 \%$ (CI $74.42-91.28$ ) reported whether male or female animals were used. $2 / 82$ or $2.44 \%$ (CI $0.30-8.53$ ) 


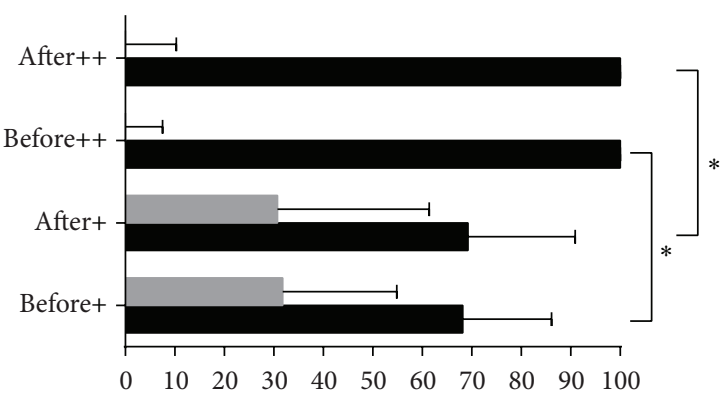

(\%)

- Use of expanded cells

Did not use expanded cells

FIGURE 2: Disaggregated proportions of papers on human $(+)$ and animal $(++)$ application of ASCs that reported the use of expanded and unexpanded cells before and after IFATS/ISCT statement (before statement, human $n=22$; after statement, human $n=13$; before statement, animal $n=47$; after statement, animal $n=34$ ), percentage and 95\% confidence interval, Fisher Exact Test $P<0.001$ with post hoc analysis, and ${ }^{*}$ significant difference $P<0.01$.

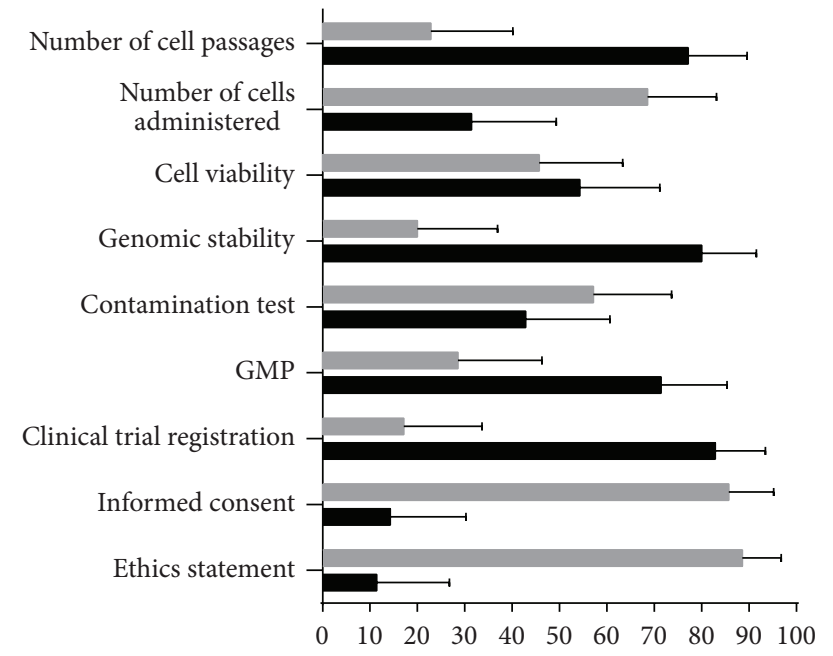

(\%)

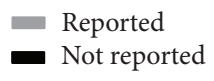

FIGURE 3: Quality of reporting papers on application of ASC in humans using selected parameters in ethics, safety, and cell characteristics $(n=35)$.

indicated how the sample size was calculated while $44 / 82$ or 53.66\% (CI 42.30-64.75) reported randomizing assignment of animals to treatment groups while $38 / 82$ or $46.34 \%$ (CI 35.25-57.70) indicated that blinding techniques were done. No paper reported on conducting genomic stability tests for the stem cells used, $2 / 82$ or $2.44 \%$ (CI $0.30-8.53$ ) reported conducting testing for possible contaminants, $78 / 82$ or $95.12 \%$ (CI 87.98-98.66) indicated the number of cells delivered, $25 / 82$ or $30.49 \%$ (CI $20.80-41.64$ ) reported checking the cell viability, and $51 / 82$ or $62.20 \%$ (CI $50.81-72.68$ ) reported the number of passages at the time the cells were used. Table 6
TABLE 5: Summary of reporting on selected key areas and parameters in papers that reported the use of ASC in humans $(n=35)$.

\begin{tabular}{lccc}
\hline \multirow{2}{*}{ Key area } & Information & \multicolumn{2}{c}{ Number of articles } \\
& & Yes & No \\
\hline \multirow{3}{*}{ Ethics } & Approval from review board & 31 & 4 \\
& Informed consent & 30 & 5 \\
& Clinical trial registration & 6 & 29 \\
\hline \multirow{3}{*}{ Safety } & Processing the cells in GMP & 10 & 25 \\
& Testing for genomic stability & 7 & 28 \\
\multirow{2}{*}{ Cell } & Screen contaminants & 20 & 15 \\
characteristics & Viability & 16 & 19 \\
& Number of cells administered & 24 & 11 \\
& Number of cell passages & 8 & 27 \\
\hline
\end{tabular}

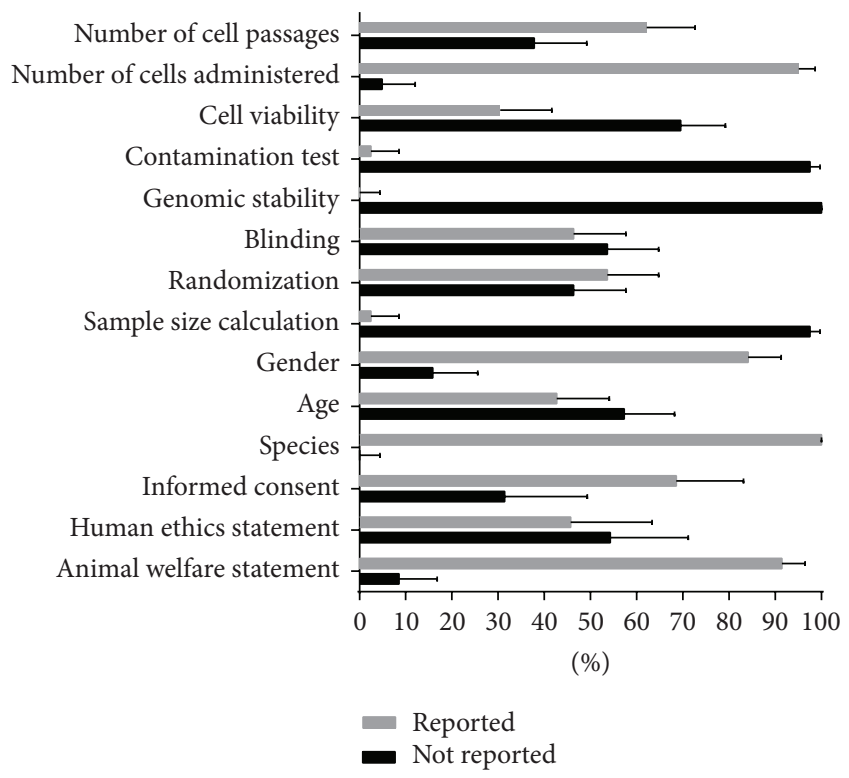

FIGURE 4: Quality of reporting papers on application of ASC in animals using selected parameters in ethics, safety, study design, and cell characteristics $(n=82)$.

summarizes the frequency of papers that reported on selected key areas and parameters of ASC use in animals.

\section{Discussion}

Transparency in reporting of research results is encouraged to hasten the standardization and reproducibility of the use of ASC for therapeutic purposes while highlighting the value of patient safety and product efficacy [126]. We assert further that accuracy in reporting the true identity of cells is very important especially that cell characteristics may vary according to source of tissue, species, site, physiological and disease condition, or age, may behave differently in a varying substrate or environment, and may provide differing outcomes when used for therapy [53, 67, 99, 104, 127, 128]. While the stem cell is a subset of the SVF it certainly is not one and, the same as the latter, contains more different types of cells other than the stem cells [3]. Expansion entails culturing 
TABLE 6: Summary of reporting on selected key areas and parameters in papers that reported the use of ASC in animals $(n=82)$.

\begin{tabular}{|c|c|c|c|}
\hline \multirow{2}{*}{ Key area } & \multirow{2}{*}{ Information } & \multicolumn{2}{|c|}{ Number of articles } \\
\hline & & Yes & No \\
\hline \multirow{3}{*}{ Ethics } & $\begin{array}{l}\text { Approval from animal ethics } \\
\text { committee }\end{array}$ & 75 & 7 \\
\hline & Human ethics statement* & 16 & 19 \\
\hline & $\begin{array}{l}\text { Informed consent from tissue } \\
\text { donors }\end{array}$ & 24 & 11 \\
\hline \multirow{3}{*}{$\begin{array}{l}\text { Animal } \\
\text { characteristics }\end{array}$} & Species & 82 & 0 \\
\hline & Age & 35 & 47 \\
\hline & Gender & 69 & 13 \\
\hline \multirow{3}{*}{ Study design } & Random allocation to groups & 44 & 38 \\
\hline & Calculation of sample size & 2 & 80 \\
\hline & Blinding & 38 & 44 \\
\hline \multirow{3}{*}{ Safety } & Testing for genomic stability & 0 & 82 \\
\hline & Screen contaminants & 2 & 80 \\
\hline & Viability & 25 & 57 \\
\hline \multirow{2}{*}{$\begin{array}{l}\text { Cell } \\
\text { characteristics }\end{array}$} & Number of cells administered & 78 & 4 \\
\hline & Number of cell passages & 51 & 31 \\
\hline
\end{tabular}

${ }^{*}$ For papers that reported utilizing human tissue $(n=35)$.

plastic adherent cell after centrifugation to retrieve adequate cell population that is needed for transplantation purposes and we considered this as the primary parameter to gauge if indeed ASC was employed. Results in this survey show that despite guidance provided by IFATS and ISCT to ascertain the cells true identity still some authors claim that they used stem cells where in fact they did not. One paper goes to the extent of highlighting a rapid way of retrieving stem cells from the lipoaspirate in just 3 to 4 hours without any culturing done prior to injection. Although we cannot discount that using SVF may produce better or poorer results than using expanded mesenchymal stem cells, transparent reporting of the true identity of the cells should always be done. When we compared how reporting fared between papers on application of ASC in humans and in animals (Figure 2), reporting on human applications tend to misreport the identity of the cells used. How potentially serious the misreporting of stem cells instead of SVFs is shown by the 95\% confidence interval for the proportion of these particular papers which was calculated to be at 2 to 20 percent.

Compliance to reporting standards and to expert's recommendation has been always a major concern even in the toptier scientific journals [129]. The current survey showed that parameters on ethics, safety, study design, and cell viability in the application of stem cells to human patients as well as in animal subjects were not fully considered during reporting. Although the information we gathered from this survey is just based on the author's reports it may mean that these data were not reported as they were not done at all or were not reported but nevertheless were done. Poor quality in reporting will have an impact on our understanding of the real benefits of ASC and may seriously affect its potential to become a standard treatment. In addition, it may to some extent negatively affect, if not endanger, the patient when results from poor reporting are used as basis. For example, obscure quality and quantity of stem cells may lead to transplanting inadequate cells resulting in ineffective results, but if the cells are more than the required number, they may potentially circulate to unintended locations and form cell aggregates that could cause pulmonary emboli or infarctions [41, 112]. Patients are on the receiving end whenever medical institutions and companies processing stem cells for commercial purposes disregard proper protocols and standards to take advantage of the hype and exaggerated promotion of stem cells as a wonder treatment for intractable disease conditions. As to safeguarding the rights of recipients, it is not enough that an informed consent is obtained but an evaluation of the patient's understanding of the risks should also be secured [130]. The results of this survey showing misreports on the use of ASC may serve not only as a guide for readers to carefully examine published research results but also as a reminder for authors to prevent further misuse.

In the light of these survey results, we continually support the need for authors, reviewers, and editors to comply with the recommendations and guidelines. Such compliance not only should be reflected during reporting but must begin as early as the research planning or conceptualization stage until implementation. This survey is also a compelling evidence for the need to further disseminate the information and guidance provided by ISCT and IFATS or conduct further discussions in seminars or conferences. Researchers actively pointing out this similar oversight to editors will be helpful [131]. More research is required to fully understand the therapeutic potential, the effectiveness, and safety of ASC and a unified global effort to comply with the existing standards would definitely provide rapid and reliable results.

\section{Conclusion}

We determined in this survey that a substantial number of published reports were not able to provide information on the characteristics of ASCs used with some erroneously referring to the SVF as stem cells. In addition, survey results suggest that there is more room for improvement in the quality of reporting in the application of ASC in humans and animals in reference to existing guidelines and recommendations.

\section{Conflict of Interests}

The authors declare that there is no conflict of interests regarding the publication of this paper.

\section{Authors' Contribution}

Ernesto Balolong and Soojung Lee contributed equally to this work and should be considered co-first authors. Jeong Ik Lee and Judee Grace Nemeno contributed equally to this work.

\section{Acknowledgments}

This research was supported by Basic Science Research Program through the National Research Foundation of Korea 
(NRF) and funded by the Ministry of Education, Science and Technology (2013R1A2A2A01015327).

\section{References}

[1] G. Q. Daley, "The promise and perils of stem cell therapeutics," Cell Stem Cell, vol. 10, no. 6, pp. 740-749, 2012.

[2] K. Drabiak-Syed, "Challenging the FDA's authority to regulate autologous adult stem cells for therapeutic use: celltex therapeutics' partnership with RNL Bio, substantial medical risks, and the implications of United States v. regenerative sciences," Health Matrix, vol. 23, no. 2, pp. 493-535, 2013.

[3] P. Bourin, B. A. Bunnell, L. Casteilla et al., "Stromal cells from the adipose tissue-derived stromal vascular fraction and culture expanded adipose tissue-derived stromal/stem cells: a joint statement of the International Federation for Adipose Therapeutics and Science (IFATS) and the International Society for Cellular Therapy (ISCT)," Cytotherapy, vol. 15, no. 6, pp. 641$648,2013$.

[4] International Society for Stem Cell, "ISSCR guidelines for the clinical translation of stem cells," in Current Protocols in Stem Cell Biology, John Wiley \& Sons, 2009.

[5] C. Kilkenny, W. J. Browne, I. C. Cuthill, M. Emerson, and D. G. Altman, "Improving bioscience research reporting: the arrive guidelines for reporting animal research," Veterinary Clinical Pathology, vol. 41, no. 1, pp. 27-31, 2012.

[6] M. MacLeod, "Why animal research needs to improve," Nature, vol. 477, no. 7366, article 511, 2011.

[7] S. C. Landis, S. G. Amara, K. Asadullah et al., "A call for transparent reporting to optimize the predictive value of preclinical research," Nature, vol. 490, no. 7419, pp. 187-191, 2012.

[8] M. Mcnutt, Journals Unite for Reproducibility, 2014, http://www .sciencemag.org/.

[9] National Institutes of Health, "Principles and guidelines for reporting preclinical research," http://www.nih.gov/about/ reporting-preclinical-research.htm.

[10] A. Bura, V. Planat-Benard, P. Bourin et al., "Phase I trial: the use of autologous cultured adipose-derived stroma/stem cells to treat patients with non-revascularizable critical limb ischemia," Cytotherapy, vol. 16, no. 2, pp. 245-257, 2014.

[11] L. Charles-de-Sá, N. F. Gontijo-de-Amorim, C. Maeda Takiya et al., "Antiaging treatment of the facial skin by fat graft and adipose-derived stem cells," Plastic and Reconstructive Surgery, vol. 135, no. 4, pp. 999-1009, 2015.

[12] Y. B. Cho, W. Y. Lee, K. J. Park, M. Kim, H.-W. Yoo, and C. S. Yu, "Autologous adipose tissue-derived stem cells for the treatment of Crohn's fistula. A phase I clinical study," Cell Transplantation, vol. 22, no. 2, pp. 279-285, 2013.

[13] S. D. Dave, A. V. Vanikar, and H. L. Trivedi, "Co-infusion of adipose tissue derived mesenchymal stem cell-differentiated insulin-making cells and haematopoietic cells with renal transplantation: a novel therapy for type 1 diabetes mellitus with endstage renal disease," BMJ Case Reports, vol. 2013, 2013.

[14] S. D. Dave, A. V. Vanikar, H. L. Trivedi, U. G. Thakkar, S. C. Gopal, and T. Chandra, "Novel therapy for insulindependent diabetes mellitus: infusion of in vitro-generated insulin-secreting cells," Clinical and Experimental Medicine, vol. 15, no. 1, pp. 41-45, 2015.

[15] B. Fang, L. Mai, N. Li, and Y. Song, "Favorable response of chronic refractory immune thrombocytopenic purpura to mesenchymal stem cells," Stem Cells and Development, vol. 21, no. 3, pp. 497-502, 2012.
[16] M. D. Herreros, M. Garcia-Arranz, H. Guadalajara, P. DeLa-Quintana, and D. Garcia-Olmo, "Autologous expanded adipose-derived stem cells for the treatment of complex cryptoglandular perianal fistulas: a phase III randomized clinical trial (FATT 1: Fistula Advanced Therapy Trial 1) and long-term evaluation," Diseases of the Colon and Rectum, vol. 55, no. 7, pp. 762-772, 2012.

[17] C. H. Jo, Y. G. Lee, W. H. Shin et al., "Intra-articular injection of mesenchymal stem cells for the treatment of osteoarthritis of the knee: a proof-of-concept clinical trial," Stem Cells, vol. 32, no. 5, pp. 1254-1266, 2014.

[18] M. Kim, I. Kim, S. K. Lee, S. I. Bang, and S. Y. Lim, “Clinical trial of autologous differentiated adipocytes from stem cells derived from human adipose tissue," Dermatologic Surgery, vol. 37, no. 6, pp. 750-759, 2011.

[19] Y. S. Kim, Y. J. Choi, D. S. Suh et al., "Mesenchymal stem cell implantation in osteoarthritic knees: is fibrin glue effective as a scaffold?" The American Journal of Sports Medicine, vol. 43, no. 1, pp. 176-185, 2014.

[20] Y. S. Kim, H. J. Lee, Y. J. Choi, Y. I. Kim, and Y. G. Koh, "Does an injection of a stromal vascular fraction containing adiposederived mesenchymal stem cells influence the outcomes of marrow stimulation in osteochondral lesions of the talus? A clinical and magnetic resonance imaging study," The American Journal of Sports Medicine, vol. 42, no. 10, pp. 2424-2434, 2014.

[21] K. S. Koh, T. S. Oh, H. Kim et al., "Clinical application of human adipose tissue-derived mesenchymal stem cells in progressive hemifacial atrophy (Parry-Romberg disease) with microfat grafting techniques using 3-dimensional computed tomography and 3-dimensional camera," Annals of Plastic Surgery, vol. 69, no. 3, pp. 331-337, 2012.

[22] Y.-G. Koh and Y.-J. Choi, "Infrapatellar fat pad-derived mesenchymal stem cell therapy for knee osteoarthritis," Knee, vol. 19, no. 6, pp. 902-907, 2012.

[23] Y.-G. Koh, Y.-J. Choi, S.-K. Kwon, Y.-S. Kim, and J.-E. Yeo, "Clinical results and second-look arthroscopic findings after treatment with adipose-derived stem cells for knee osteoarthritis," Knee Surgery, Sports Traumatology, Arthroscopy, vol. 23, no. 5, pp. 1308-1316, 2015.

[24] Y.-G. Koh, S.-B. Jo, O.-R. Kwon et al., "Mesenchymal stem cell injections improve symptoms of knee osteoarthritis," Arthroscopy, vol. 29, no. 4, pp. 748-755, 2013.

[25] Y. G. Koh, O. R. Kwon, Y. S. Kim, and Y. J. Choi, “Comparative outcomes of open-wedge high tibial osteotomy with plateletrich plasma alone or in combination with mesenchymal stem cell treatment: a prospective study," Arthroscopy, vol. 30, no. 11, pp. 1453-1460, 2014.

[26] S.-F. T. Kølle, A. Fischer-Nielsen, A. B. Mathiasen et al., "Enrichment of autologous fat grafts with ex-vivo expanded adipose tissue-derived stem cells for graft survival: a randomised placebo-controlled trial," The Lancet, vol. 382, no. 9898, pp. 11131120, 2013.

[27] H. C. Lee, S. G. An, H. W. Lee et al., "Safety and effect of adipose tissue-derived stem cell implantation in patients with critical limb ischemia-a pilot study," Circulation Journal, vol. 76, no. 7, pp. 1750-1760, 2012.

[28] W. Y. Lee, K. J. Park, Y. B. Cho et al., "Autologous adipose tissue-derived stem cells treatment demonstrated favorable and sustainable therapeutic effect for crohn's fistula," Stem Cells, vol. 31, no. 11, pp. 2575-2581, 2013. 
[29] J. Pak, "Regeneration of human bones in hip osteonecrosis and human cartilage in knee osteoarthritis with autologous adiposetissue-derived stem cells: a case series," Journal of Medical Case Reports, vol. 5, article 296, 2011.

[30] R. F. Saidi, B. Rajeshkumar, A. Shariftabrizi et al., "Human adipose-derived mesenchymal stem cells attenuate liver ischemia-reperfusion injury and promote liver regeneration," Surgery, vol. 156, no. 5, pp. 1225-1231, 2014.

[31] G. K. Sándor, J. Numminen, J. Wolff et al., "Adipose stem cells used to reconstruct 13 cases with cranio-maxillofacial hardtissue defects," Stem Cells Translational Medicine, vol. 3, no. 4, pp. 530-540, 2014.

[32] R. Sanz-Baro, M. Garcia-Arranz, H. Guadalajara, P. de la Quintana, M. D. Herreros, and D. Garcia-Olmo, "First-inhuman case study: pregnancy in women with Crohn's perianal fistula treated with adipose-derived stem cell: a safety study," Stem Cells Translational Medicine, vol. 4, no. 6, pp. 598-602, 2015.

[33] N. Scuderi, S. Ceccarelli, M. G. Onesti et al., "Human adiposederived stromal cells for cell-based therapies in the treatment of systemic sclerosis," Cell Transplantation, vol. 22, no. 5, pp. 779795, 2013.

[34] A. Sterodimas, J. De Faria, B. Nicaretta, and F. Boriani, "Autologous fat transplantation versus adipose-derived stem cellenriched lipografts: a study," Aesthetic Surgery Journal, vol. 31, no. 6, pp. 682-693, 2011.

[35] H. M. Sung, I. S. Suh, H.-B. Lee, K. S. Tak, K. M. Moon, and M. S. Jung, "Case reports of adipose-derived stem cell therapy for nasal skin necrosis after filler injection," Archives of Plastic Surgery, vol. 39, no. 1, pp. 51-54, 2012.

[36] D. Y. S. Tanikawa, M. Aguena, D. F. Bueno, M. R. Passos-Bueno, and N. Alonso, "Fat grafts supplemented with adipose-derived stromal cells in the rehabilitation of patients with craniofacial microsomia," Plastic and Reconstructive Surgery, vol. 132, no. 1, pp. 141-152, 2013.

[37] U. G. Thakkar, H. L. Trivedi, A. V. Vanikar, and S. D. Dave, "Insulin-secreting adipose-derived mesenchymal stromal cells with bone marrow-derived hematopoietic stem cells from autologous and allogenic sources for type 1 diabetes mellitus," Cytotherapy, vol. 17, no. 7, pp. 940-947, 2015.

[38] T. Thesleff, K. Lehtimäki, T. Niskakangas et al., "Cranioplasty with adipose-derived stem cells and biomaterial: a novel method for cranial reconstruction," Neurosurgery, vol. 68, no. 6, pp. 1535-1540, 2011.

[39] A. Tzouvelekis, V. Paspaliaris, G. Koliakos et al., "A prospective, non-randomized, no placebo-controlled, phase Ib clinical trial to study the safety of the adipose derived stromal cells-stromal vascular fraction in idiopathic pulmonary fibrosis," Journal of Translational Medicine, vol. 11, article 171, 2013.

[40] F. De La Portilla, F. Alba, D. García-Olmo, J. M. Herrerías, F. X. González, and A. Galindo, "Expanded allogeneic adiposederived stem cells (eASCs) for the treatment of complex perianal fistula in Crohn's disease: results from a multicenter phase I/IIa clinical trial," International Journal of Colorectal Disease, vol. 28, no. 3, pp. 313-323, 2013.

[41] J. W. Jung, M. Kwon, J. C. Choi et al., "Familial occurrence of pulmonary embolism after intravenous, adipose tissue-derived stem cell therapy," Yonsei Medical Journal, vol. 54, no. 5, pp. 1293-1296, 2013.

[42] J. Pak, J.-J. Chang, J. H. Lee, and S. H. Lee, "Safety reporting on implantation of autologous adipose tissue-derived stem cells with platelet-rich plasma into human articular joints," $B M C$ Musculoskeletal Disorders, vol. 14, article 337, 2013.

[43] A. V. Vanikar, H. L. Trivedi, A. Kumar et al., "Co-infusion of donor adipose tissue-derived mesenchymal and hematopoietic stem cells helps safe minimization of immunosuppression in renal transplantation-single center experience," Renal Failure, vol. 36, no. 9, pp. 1376-1384, 2014.

[44] G. Zheng, L. Huang, H. Tong et al., "Treatment of acute respiratory distress syndrome with allogeneic adipose-derived mesenchymal stem cells: a randomized, placebo-controlled pilot study," Respiratory Research, vol. 15, article 39, 2014.

[45] A. D. M. Carvalho, P. R. Badial, L. E. C. Álvarez et al., "Equine tendonitis therapy using mesenchymal stem cells and platelet concentrates: a randomized controlled trial," Stem Cell Research and Therapy, vol. 4, no. 4, article 85, 2013.

[46] J. M. Vilar, M. Morales, A. Santana et al., "Controlled, blinded force platform analysis of the effect of intraarticular injection of autologous adipose-derived mesenchymal stem cells associated to PRGF-Endoret in osteoarthritic dogs," BMC Veterinary Research, vol. 9, article 131, 2013.

[47] S. Y. Tsai, Y. G. Huan, L. L. Cheun, L. S. Yeh, and C. S. Lin, "Intraarticular transplantation of porcine adipose-derived stem cells for the treatment of canine osteoarthritis: a pilot study," World Journal of Transplantation, vol. 4, no. 3, pp. 196-205, 2014.

[48] Z. Y. A. Elmageed, Y. Yang, R. Thomas et al., "Neoplastic reprogramming of patient-derived adipose stem cells by prostate cancer cell-associated exosomes," Stem Cells, vol. 32, no. 4, pp. 983-997, 2014.

[49] H. Agrawal, H. Shang, A. Sattah, N. Yang, S. M. Peirce, and A. J. Katz, "Human adipose-derived stromal/stem cells demonstrate short-lived persistence after implantation in both an immunocompetent and an immunocompromised murine model," Stem Cell Research \& Therapy, vol. 5, no. 6, article 142, 2014.

[50] J. O. Ahn, H. W. Lee, K. W. Seo, S. K. Kang, J. C. Ra, and H. Y. Youn, "Anti-tumor effect of adipose tissue derivedmesenchymal stem cells expressing interferon- $\beta$ and treatment with cisplatin in a xenograft mouse model for canine melanoma," PLoS ONE, vol. 8, no. 9, Article ID e74897, 11 pages, 2013.

[51] C. Altaner, V. Altanerova, M. Cihova et al., "Complete regression of glioblastoma by mesenchymal stem cells mediated prodrug gene therapy simulating clinical therapeutic scenario," International Journal of Cancer, vol. 134, no. 6, pp. 1458-1465, 2014.

[52] V. Altanerova, M. Cihova, M. Babic et al., "Human adipose tissue-derived mesenchymal stem cells expressing yeast cytosinedeaminase::uracil phosphoribosyltransferase inhibit intracerebral rat glioblastoma," International Journal of Cancer, vol. 130, no. 10, pp. 2455-2463, 2012.

[53] M. A. Antunes, S. C. Abreu, F. F. Cruz et al., "Effects of different mesenchymal stromal cell sources and delivery routes in experimental emphysema," Respiratory Research, vol. 15, no. 1, article 118, 2014.

[54] C. Cakici, B. Buyrukcu, G. Duruksu et al., "Recovery of fertility in azoospermia rats after injection of adipose-tissuederived mesenchymal stem cells: the sperm generation," BioMed Research International, vol. 2013, Article ID 529589, 18 pages, 2013. 
[55] P. Chang, Y. Qu, Y. Liu et al., "Multi-therapeutic effects of human adipose-derived mesenchymal stem cells on radiationinduced intestinal injury," Cell Death and Disease, vol. 4, article e685, 2013.

[56] H.-H. Chen, C.-L. Chang, K.-C. Lin et al., "Melatonin augments apoptotic adipose-derived mesenchymal stem cell treatment against sepsis-induced acute lung injury," American Journal of Translational Research, vol. 6, no. 5, pp. 439-458, 2014.

[57] H.-H. Chen, K.-C. Lin, C. G. Wallace et al., "Additional benefit of combined therapy with melatonin and apoptotic adiposederived mesenchymal stem cell against sepsis-induced kidney injury," Journal of Pineal Research, vol. 57, no. 1, pp. 16-32, 2014.

[58] Y.-T. Chen, H.-J. Chiang, C.-H. Chen et al., "Melatonin treatment further improves adipose-derived mesenchymal stem cell therapy for acute interstitial cystitis in rat," Journal of Pineal Research, vol. 57, no. 3, pp. 248-261, 2014.

[59] Y.-T. Chen, C.-K. Sun, Y.-C. Lin et al., "Adipose-derived mesenchymal stem cell protects kidneys against ischemiareperfusion injury through suppressing oxidative stress and inflammatory reaction," Journal of Translational Medicine, vol. 9, article 51, 2011

[60] Y.-T. Chen, C.-C. Yang, Y.-Y. Zhen et al., "Cyclosporine-assisted adipose-derived mesenchymal stem cell therapy to mitigate acute kidney ischemia-reperfusion injury," Stem Cell Research and Therapy, vol. 4, no. 3, article 62, 2013.

[61] E. W. Choi, T. W. Yun, J. W. Song, M. Lee, J. Yang, and K.-S. Choi, "Preventive effects of CTLA4Ig-overexpressing adipose tissuederived mesenchymal stromal cells in rheumatoid arthritis," Cytotherapy, vol. 17, no. 3, pp. 271-282, 2015.

[62] H. J. Choi, J. M. Kim, E. Kwon et al., "Establishment of efficacy and safety assessment of human adipose tissue-derived mesenchymal stem cells (hATMSCs) in a nude rat femoral segmental defect model," Journal of Korean Medical Science, vol. 26, no. 4, pp. 482-491, 2011.

[63] S. A. Choi, J. Y. Lee, K.-C. Wang et al., "Human adipose tissuederived mesenchymal stem cells: characteristics and therapeutic potential as cellular vehicles for prodrug gene therapy against brainstem gliomas," European Journal of Cancer, vol. 48, no. 1, pp. 129-137, 2012.

[64] B. H. Chung, S. W. Lim, K. C. Doh, S. G. Piao, S. B. Heo, and C. W. Yang, "Human adipose tissue derived mesenchymal stem cells aggravate chronic cyclosporin nephrotoxicity by the induction of oxidative stress," PLoS ONE, vol. 8, no. 3, Article ID e59693, 2013.

[65] A. Eirin, X.-Y. Zhu, J. D. Krier et al., "Adipose tissue-derived mesenchymal stem cells improve revascularization outcomes to restore renal function in swine atherosclerotic renal artery stenosis," Stem Cells, vol. 30, no. 5, pp. 1030-1041, 2012.

[66] T. Georgiev-Hristov, M. García-Arranz, I. García-Gómez et al., "Sutures enriched with adipose-derived stem cells decrease the local acute inflammation after tracheal anastomosis in a murine model," European Journal of Cardio-thoracic Surgery, vol. 42, no. 3, pp. e40-e47, 2012.

[67] M. Gutiérrez-Fernández, B. Rodríguez-Frutos, J. RamosCejudo et al., "Comparison between xenogeneic and allogeneic adipose mesenchymal stem cells in the treatment of acute cerebral infarct: proof of concept in rats," Journal of Translational Medicine, vol. 13, article 46, 2015.

[68] S. E. Hanson, K. R. Kleinbeck, D. Cantu et al., "Local delivery of allogeneic bone marrow and adipose tissue-derived mesenchymal stromal cells for cutaneous wound healing in a porcine model," Journal of Tissue Engineering and Regenerative Medicine, 2013.

[69] S. J. Hong, D. Hou, T. J. Brinton et al., "Intracoronary and retrograde coronary venous myocardial delivery of adiposederived stem cells in swine infarction lead to transient myocardial trapping with predominant pulmonary redistribution," Catheterization and Cardiovascular Interventions, vol. 83, no. 1, pp. E17-E25, 2014.

[70] M.-J. Hung, M.-C. Wen, Y.-T. Huang, G.-D. Chen, M.-M. Chou, and V. C. Yang, "Fascia tissue engineering with human adipose-derived stem cells in a murine model: implications for pelvic floor reconstruction," Journal of the Formosan Medical Association, vol. 113, no. 10, pp. 704-715, 2014.

[71] W. Jiang, G. Liang, X. Li et al., "Intracarotid transplantation of autologous adipose-derived mesenchymal stem cells significantly improves neurological deficits in rats after MCAo," Journal of Materials Science: Materials in Medicine, vol. 25, no. 5, pp. 1357-1366, 2014.

[72] X. Jiang, X. Jiang, C. Qu et al., "Intravenous delivery of adiposederived mesenchymal stromal cells attenuates acute radiationinduced lung injury in rats," Cytotherapy, vol. 17, no. 5, pp. 560570, 2015.

[73] P. Kaengkan, S. E. Baek, J. Y. Kim et al., "Administration of mesenchymal stem cells and ziprasidone enhanced amelioration of ischemic brain damage in rats," Molecules and Cells, vol. 36, no. 6, pp. 534-541, 2013.

[74] B.-J. Kang, H.-H. Ryu, S. S. Park et al., "Comparing the osteogenic potential of canine mesenchymal stem cells derived from adipose tissues, bone marrow, umbilical cord blood, and Wharton's jelly for treating bone defects," Journal of Veterinary Science, vol. 13, no. 3, pp. 299-310, 2012.

[75] B.-J. Kang, H.-H. Ryu, S.-S. Park et al., "Effect of Matrigel on the osteogenic potential of canine adipose tissue-derived mesenchymal stem cells," Journal of Veterinary Medical Science, vol. 74, no. 7, pp. 827-836, 2012.

[76] A. A. Karpov, Y. K. Uspenskaya, S. M. Minasian et al., "The effect of bone marrow- and adipose tissue-derived mesenchymal stem cell transplantation on myocardial remodelling in the rat model of ischaemic heart failure," International Journal of Experimental Pathology, vol. 94, no. 3, pp. 169-177, 2013.

[77] H. Kim, M. Mizuno, K. Furuhashi et al., "Rat adipose tissuederived stem cells attenuate peritoneal injuries in rat zymosaninduced peritonitis accompanied by complement activation," Cytotherapy, vol. 16, no. 3, pp. 357-368, 2014.

[78] J. H. Kim, D. J. Park, J. C. Yun et al., "Human adipose tissuederived mesenchymal stem cells protect kidneys from cisplatin nephrotoxicity in rats," American Journal of Physiology-Renal Physiology, vol. 302, no. 9, pp. F1141-F1150, 2012.

[79] S. H. Kim, S. W. Chung, and J. H. Oh, "Expression of insulin-like growth factor type 1 receptor and myosin heavy chain in rabbit's rotator cuff muscle after injection of adipose-derived stem cell," Knee Surgery, Sports Traumatology, Arthroscopy, vol. 22, no. 11, pp. 2867-2873, 2013.

[80] E. Koellensperger, K. Lampe, A. Beierfuss, F. Gramley, G. Germann, and U. Leimer, "Intracutaneously injected human adipose tissue-derived stem cells in a mouse model stay at the site of injection," Journal of Plastic, Reconstructive and Aesthetic Surgery, vol. 67, no. 6, pp. 844-850, 2014.

[81] T.-J. Lee, S. H. Bhang, H. S. Yang et al., "Enhancement of longterm angiogenic efficacy of adipose stem cells by delivery of FGF2," Microvascular Research, vol. 84, no. 1, pp. 1-8, 2012. 
[82] D. Li, Y. Fang, P. Wang, W. Shan, Z. Zuo, and L. Xie, "Autologous transplantation of adipose-derived mesenchymal stem cells attenuates cerebral ischemia and reperfusion injury through suppressing apoptosis and inducible nitric oxide synthase," International Journal of Molecular Medicine, vol. 29, no. 5, pp. 848-854, 2012.

[83] Q. Li, J. Tang, R. Wang et al., "Comparing the chondrogenic potential in vivo of autogeneic mesenchymal stem cells derived from different tissues," Artificial Cells, Blood Substitutes, and Biotechnology, vol. 39, no. 1, pp. 31-38, 2011.

[84] J.-Y. Lim, J. C. Ra, I. S. Shin et al., "Systemic transplantation of human adipose tissue-derived mesenchymal stem cells for the regeneration of irradiation-induced salivary gland damage," PLoS ONE, vol. 8, no. 8, Article ID e71167, 2013.

[85] R.-Z. Lin, R. Moreno-Luna, D. Li, S.-C. Jaminet, A. K. Greene, and J. M. Melero-Martin, "Human endothelial colonyforming cells serve as trophic mediators for mesenchymal stem cell engraftment via paracrine signaling," Proceedings of the National Academy of Sciences of the United States of America, vol. 111, no. 28, pp. 10137-10142, 2014.

[86] L. Liu, P. W. Y. Chiu, P. K. Lam et al., "Effect of local injection of mesenchymal stem cells on healing of sutured gastric perforation in an experimental model," British Journal of Surgery, vol. 102, no. 2, pp. e158-e168, 2015.

[87] X.-L. Liu, W. Zhang, and S.-J. Tang, "Intracranial transplantation of human adipose-derived stem cells promotes the expression of neurotrophic factors and nerve repair in rats of cerebral ischemia-reperfusion injury," International Journal of Clinical and Experimental Pathology, vol. 7, no. 1, pp. 174-183, 2014.

[88] Z. M. MacIsaac, H. Shang, H. Agrawal, N. Yang, A. Parker, and A. J. Katz, "Long-term in-vivo tumorigenic assessment of human culture-expanded adipose stromal/stem cells," Experimental Cell Research, vol. 318, no. 4, pp. 416-423, 2012.

[89] E. K. Mader, G. Butler, S. C. Dowdy et al., "Optimizing patient derived mesenchymal stem cells as virus carriers for a Phase I clinical trial in ovarian cancer," Journal of Translational Medicine, vol. 11, article 20, 2013.

[90] M. K. Maharlooei, M. Bagheri, Z. Solhjou et al., "Adipose tissue derived mesenchymal stem cell (AD-MSC) promotes skin wound healing in diabetic rats," Diabetes Research and Clinical Practice, vol. 93, no. 2, pp. 228-234, 2011.

[91] C. N. Manning, A. G. Schwartz, W. Liu et al., "Controlled delivery of mesenchymal stem cells and growth factors using a nanofiber scaffold for tendon repair," Acta Biomaterialia, vol. 9, no. 6, pp. 6905-6914, 2013.

[92] S. Marconi, M. Bonaconsa, I. Scambi et al., "Systemic treatment with adipose-derived mesenchymal stem cells ameliorates clinical and pathological features in the amyotrophic lateral sclerosis murine model," Neuroscience, vol. 248, pp. 333-343, 2013.

[93] A. Mirsaidi, K. Genelin, J. R. Vetsch et al., "Therapeutic potential of adipose-derived stromal cells in age-related osteoporosis," Biomaterials, vol. 35, no. 26, pp. 7326-7335, 2014.

[94] S. Nishiwaki, T. Nakayama, S. Saito et al., "Efficacy and safety of human adipose tissue-derived mesenchymal stem cells for supporting hematopoiesis," International Journal of Hematology, vol. 96, no. 3, pp. 295-300, 2012.

[95] H. Okura, M. Soeda, M. Morita et al., "Therapeutic potential of human adipose tissue-derived multi-lineage progenitor cells in liver fibrosis," Biochemical and Biophysical Research Communications, vol. 456, no. 4, pp. 860-865, 2015.
[96] F. A. Pinarli, N. N. Turan, F. G. Pinarli et al., "Resveratrol and adipose-derived mesenchymal stem cells are effective in the prevention and treatment of doxorubicin cardiotoxicity in rats," Pediatric Hematology and Oncology, vol. 30, no. 3, pp. 226-238, 2013.

[97] N. Pourebrahim, B. Hashemibeni, S. Shahnaseri et al., "A comparison of tissue-engineered bone from adipose-derived stem cell with autogenous bone repair in maxillary alveolar cleft model in dogs," International Journal of Oral and Maxillofacial Surgery, vol. 42, no. 5, pp. 562-568, 2013.

[98] I. R. Kashani, A. Hedayatpour, P. Pasbakhsh et al., " $17 \beta$-estradiol enhances the efficacy of adipose-derived mesenchymal stem cells on remyelination in mouse model of multiple sclerosis," Acta Medica Iranica, vol. 50, no. 12, pp. 789-797, 2012.

[99] R. C. Rennert, M. Sorkin, M. Januszyk et al., "Diabetes impairs the angiogenic potential of adipose-derived stem cells by selectively depleting cellular subpopulations," Stem Cell Research and Therapy, vol. 5, no. 3, article 79, 2014.

[100] L. Riera del Moral, C. Largo, J. R. Ramirez et al., "Potential of mesenchymal stem cell in stabilization of abdominal aortic aneurysm sac," Journal of Surgical Research, vol. 195, no. 1, pp. 325-333, 2015.

[101] C. M. Runyan, S. T. Ali, W. Chen et al., "Bone tissue engineering by way of allograft revitalization: mechanistic and mechanical investigations using a porcine model," Journal of Oral and Maxillofacial Surgery, vol. 72, no. 5, pp. 1000-e11, 2014.

[102] G. K. B. Sándor, “Tissue engineering of bone: clinical observations with adipose-derived stem cells, resorbable scaffolds, and growth factors," Annals of Maxillofacial Surgery, vol. 2, no. 1, pp. 8-11, 2012.

[103] A. Schwerk, J. Altschüler, M. Roch et al., "Human adiposederived mesenchymal stromal cells increase endogenous neurogenesis in the rat subventricular zone acutely after 6hydroxydopamine lesioning," Cytotherapy, vol. 17, no. 2, pp. 199-214, 2015.

[104] B. A. Scruggs, J. A. Semon, X. Zhang et al., "Age of the donor reduces the ability of human adipose-derived stem cells to alleviate symptoms in the experimental autoimmune encephalomyelitis mouse model," Stem Cells Translational Medicine, vol. 2, no. 10, pp. 797-807, 2013.

[105] S. Shiratsuki, S. Terai, Y. Murata et al., "Enhanced survival of mice infused with bone marrow-derived as compared with adipose-derived mesenchymal stem cells," Hepatology Research, 2015.

[106] P. Streckbein, S. Jäckel, C.-Y. Malik et al., "Reconstruction of critical-size mandibular defects in immunoincompetent rats with human adipose-derived stromal cells," Journal of CranioMaxillofacial Surgery, vol. 41, no. 6, pp. 496-503, 2013.

[107] C. V. Suartz, S. Gaiba, J. P. de França, A. C. Aloise, and L. M. Ferreira, "Adipose-derived stem cells (ADSC) in the viability of a random pattern dorsal skin flap in rats," Acta Cirúrgica Brasileira, vol. 29, pp. 1-5, 2014.

[108] S. Sugitani, K. Tsuruma, Y. Ohno et al., "The potential neuroprotective effect of human adipose stem cells conditioned medium against light-induced retinal damage," Experimental Eye Research, vol. 116, pp. 254-264, 2013.

[109] C.-K. Sun, Y.-Y. Zhen, S. Leu et al., "Direct implantation versus platelet-rich fibrin-embedded adipose-derived mesenchymal stem cells in treating rat acute myocardial infarction," International Journal of Cardiology, vol. 173, no. 3, pp. 410-423, 2014.

[110] C.-K. Sun, S. Leu, S.-Y. Hsu et al., "Mixed serum-deprived and normal adipose-derived mesenchymal stem cells against acute 
lung ischemia-reperfusion injury in rats," American Journal of Translational Research, vol. 7, no. 2, pp. 209-231, 2015.

[111] C.-K. Sun, C.-H. Yen, Y.-C. Lin et al., "Autologous transplantation of adipose-derived mesenchymal stem cells markedly reduced acute ischemia-reperfusion lung injury in a rodent model," Journal of Translational Medicine, vol. 9, no. 1, article 118, 2011.

[112] K. Tatsumi, K. Ohashi, Y. Matsubara et al., "Tissue factor triggers procoagulation in transplanted mesenchymal stem cells leading to thromboembolism," Biochemical and Biophysical Research Communications, vol. 431, no. 2, pp. 203-209, 2013.

[113] K. Toupet, M. Maumus, J.-A. Peyrafitte et al., "Long-term detection of human adipose-derived mesenchymal stem cells after intraarticular injection in SCID mice," Arthritis and Rheumatism, vol. 65, no. 7, pp. 1786-1794, 2013.

[114] K. Tsuruma, M. Yamauchi, S. Sugitani et al., "Progranulin, a major secreted protein of mouse adipose-derived stem cells, inhibits light-induced retinal degeneration," Stem Cells Translational Medicine, vol. 3, no. 1, pp. 42-53, 2014.

[115] N. M. Vieira, M. Valadares, E. Zucconi et al., "Human adiposederived mesenchymal stromal cells injected systemically into GRMD dogs without immunosuppression are able to reach the host muscle and express human dystrophin," Cell Transplantation, vol. 21, no. 7, pp. 1407-1417, 2012.

[116] O. F. Vila, J. R. Bagó, M. Navarro et al., "Calcium phosphate glass improves angiogenesis capacity of poly(lactic acid) scaffolds and stimulates differentiation of adipose tissue-derived mesenchymal stromal cells to the endothelial lineage," Journal of Biomedical Materials Research Part A, vol. 101, no. 4, pp. 932941, 2013.

[117] X. Wang, C. Liu, S. Li et al., "Hypoxia precondition promotes adipose-derived mesenchymal stem cells based repair of diabetic erectile dysfunction via augmenting angiogenesis and neuroprotection," PLoS ONE, vol. 10, no. 3, Article ID e0118951, 18 pages, 2015.

[118] Z. J. Wang, R. Z. An, J. Y. Zhao et al., "Repair of articular cartilage defects by tissue-engineered cartilage constructed with adipose-derived stem cells and acellular cartilaginous matrix in rabbits," Genetics and Molecular Research, vol. 13, no. 2, pp. 4599-4606, 2014.

[119] J. Xiao, C. Zhang, Y. Zhang et al., "Transplantation of adiposederived mesenchymal stem cells into a murine model of passive chronic immune thrombocytopenia," Transfusion, vol. 52, no. 12, pp. 2551-2558, 2012.

[120] K.-L. Yang, J.-T. Lee, C.-Y. Pang et al., "Human adipose-derived stem cells for the treatment of intracerebral hemorrhage in rats via femoral intravenous injection," Cellular and Molecular Biology Letters, vol. 17, no. 3, pp. 376-392, 2012.

[121] J. N. Yaochite, C. Caliari-Oliveira, L. E. de Souza et al., "Therapeutic efficacy and biodistribution of allogeneic mesenchymal stem cells delivered by intrasplenic and intrapancreatic routes in streptozotocin-induced diabetic mice," Stem Cell Research \& Therapy, vol. 6, article 31, 2015.

[122] H.-K. Yip, Y.-C. Chang, C. G. Wallace et al., "Melatonin treatment improves adipose-derived mesenchymal stem cell therapy for acute lung ischemia-reperfusion injury," Journal of Pineal Research, vol. 54, no. 2, pp. 207-221, 2013.

[123] H. Zhang, X. Qiu, A. W. Shindel et al., "Adipose tissue-derived stem cells ameliorate diabetic bladder dysfunction in a type II diabetic rat model," Stem Cells and Development, vol. 21, no. 9, pp. 1391-1400, 2012.
[124] Z. Zhang, S. Li, M. Cui et al., "Rosuvastatin enhances the therapeutic efficacy of adipose-derived mesenchymal stem cells for myocardial infarction via PI3K/Akt and MEK/ERK pathways," Basic Research in Cardiology, vol. 108, no. 2, article 333, 2013.

[125] Y. Zhou, M. Sun, H. Li et al., "Recovery of behavioral symptoms in hemi-parkinsonian rhesus monkeys through combined gene and stem cell therapy," Cytotherapy, vol. 15, no. 4, pp. 467-480, 2013.

[126] J. M. Gimble, B. A. Bunnell, E. S. Chiu, and F. Guilak, "Concise review: adipose-derived stromal vascular fraction cells and stem cells: let's not get lost in translation," Stem Cells, vol. 29, no. 5, pp. 749-754, 2011.

[127] A. Keating, "Mesenchymal stromal cells: new directions," Cell Stem Cell, vol. 10, no. 6, pp. 709-716, 2012.

[128] Y. Fu, R. Li, J. Zhong et al., "Adipogenic differentiation potential of adipose-derived mesenchymal stem cells from ovariectomized mice," Cell Proliferation, vol. 47, no. 6, pp. 604-614, 2014.

[129] D. Baker, K. Lidster, A. Sottomayor, and S. Amor, "Two years later: journals are not yet enforcing the ARRIVE guidelines on reporting standards for pre-clinical animal studies," PLoS Biology, vol. 12, no. 1, Article ID e1001756, 2014.

[130] I. Hyun, O. Lindvall, L. Ährlund-Richter et al., "New ISSCR guidelines underscore major principles for responsible translational stem cell research," Cell Stem Cell, vol. 3, no. 6, pp. 607609, 2008.

[131] C.-W. Ha and Y.-B. Park, "Mesenchymal stem cell injection for osteochondral lesions of the talus: letter to the editor," The American Journal of Sports Medicine, vol. 42, no. 6, pp. NP34NP35, 2014. 

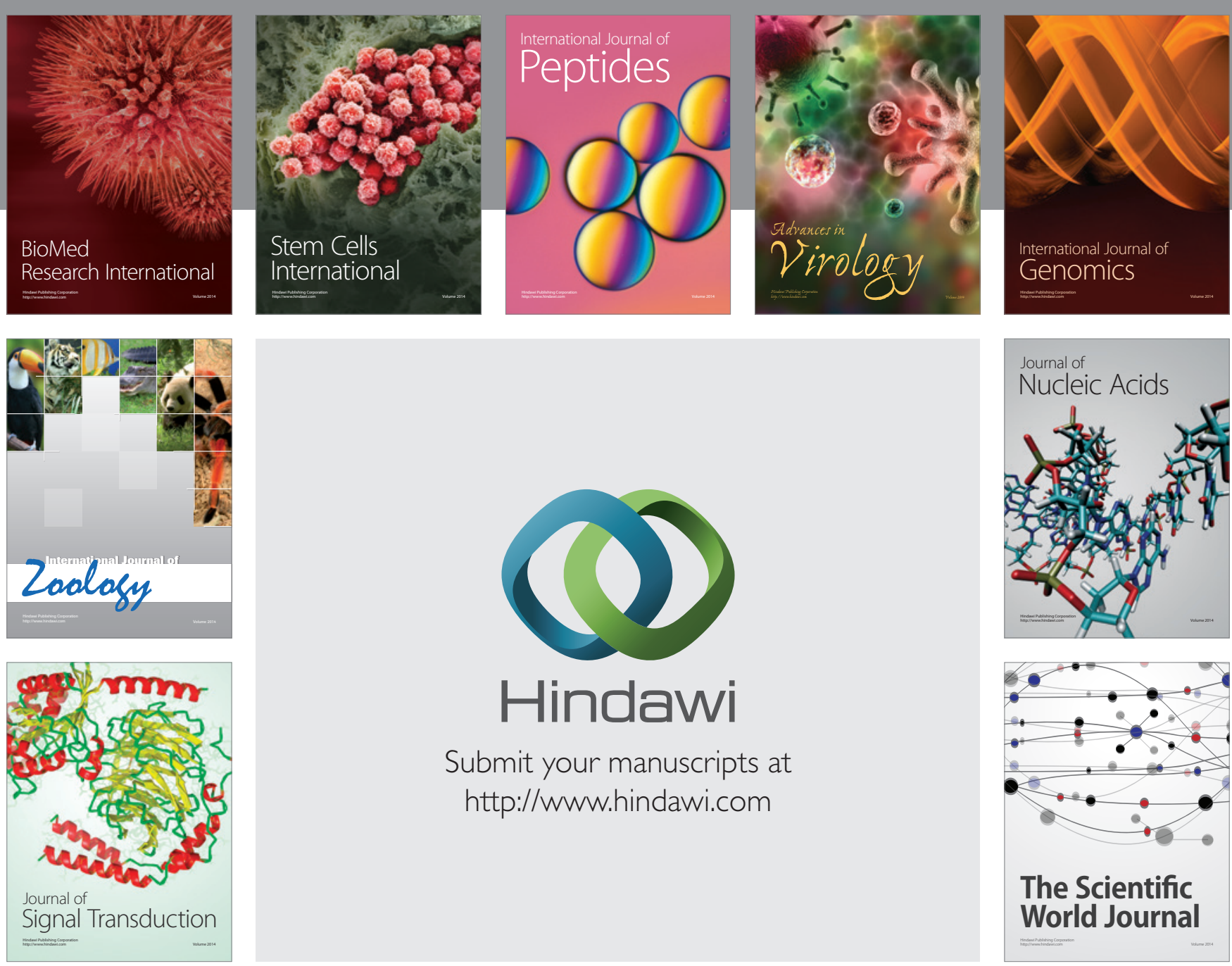

Submit your manuscripts at

http://www.hindawi.com
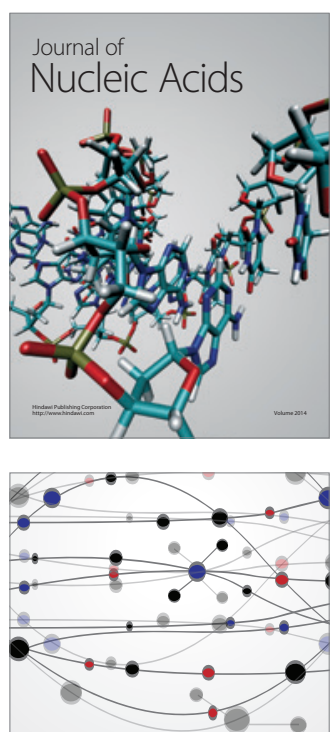

The Scientific World Journal
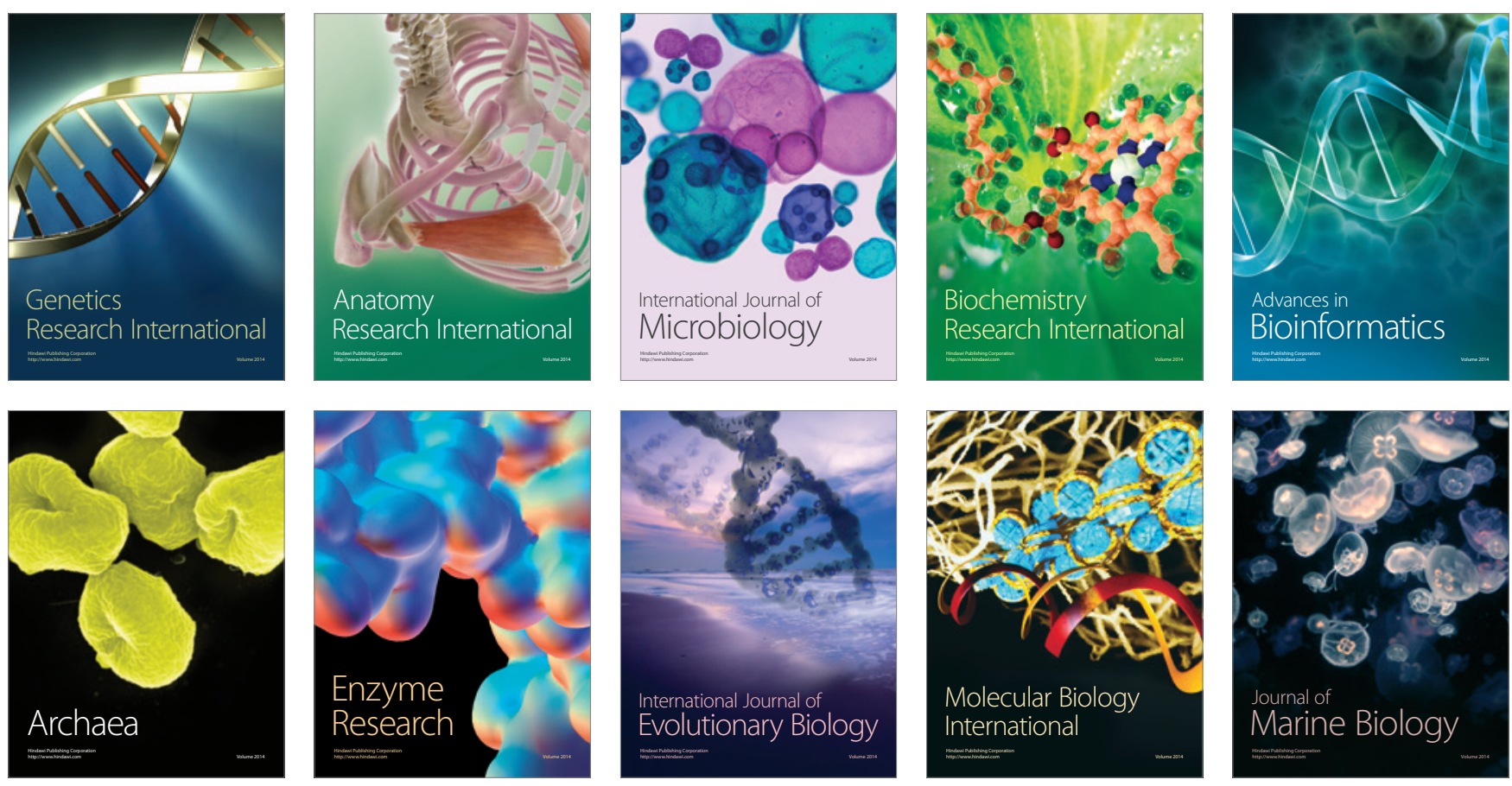